\title{
Effects of Croton urucurana Extracts and Crude Resin on Anagasta kuehniella (Lepidoptera: Pyralidae)
}

\author{
Luciana Barboza Silva ${ }^{1 *}$, Walciane Silva ${ }^{2}$, Maria Ligia Rodrigues Macedo ${ }^{3}$ and Marize \\ Terezinha Lopes Pereira Peres ${ }^{4}$ \\ ${ }^{I}$ Departamento de Entomologia; Universidade Federal de Viçosa; Viçosa - MG - Brasil. ${ }^{2}$ Instituto de Química; \\ Universidade de São Paulo; São Paulo - SP - Brasil. ${ }^{3}$ Departamento de Tecnologia de Alimentos e Saúde Pública; \\ Universidade Federal de Mato Grosso do Sul; Campo Grande - MS - Brasil. ${ }^{4}$ Departamento de Hidráulica e \\ Transportes; Centro de Ciências Exatas e Tecnologia;Universidade Federal de Mato Grosso do Sul; Campo \\ Grande - MS - Brasil
}

\begin{abstract}
Hundreds of plant species have been studied in order to find out the active ingredient responsible for their insecticidal activity against the pests of economic importance. To verify the insecticidal activity in the husk of stem of Croton urucurana Baillon 1864 (Euphorbiaceae) against Anagasta kuehniella Zeller 1879 (Lepidoptera: Pyralidae), the methanolic (EMeOH) extract, dichloromethane fraction (FDM), ethyl acetate fraction (FAE) and crude resin, incorporated into an artificial diet were evaluated. EMeOH $(0.5,1.0$ and 2.0\%) and crude resin (2.0\%) interfered with neither the weight nor the survival of fourth instar larvae and other analyzed parameters. FDM (2.0\%) fraction caused mortality of 65\%, and the artificial diet containing 2.0, 1.0 and 0.5\% FAE caused 100, 55 and $68 \%$ mortality respectively when compared with the control, confirming the least efficiency rates of food conversion for FDM(2.0\%) and FAE(1.0\%). The tryptic analysis performed with the midgut fluid of fourth-instar larvae demonstrated that tryptic and chymiotryptic activities for the larvae fed artificial diet containing EMeOH and crude resin were not different.
\end{abstract}

Key words: Euphorbiaceae, insecticide, 'sangra d'água', meal moth, toxicity

\section{INTRODUCTION}

Given increasing problems with resistance and impact on non-target organisms related to the use of synthetic insecticides, there is an urgent need for the development of safer alternatives, such as insecticide proteins that interfere with the digestive process (Carlini and Grossi-de-Sá, 2002; Montesdeoca et al., 2005) and the use of substances from the secondary metabolism of plants with insecticidal activity (Omar et al., 2000;
Simões et al., 2002; Medina et al., 2003; Akhtar and Isman, 2004).

It is believed that many secondary metabolites found in the plants occurred originally as a result of natural selection during the coevolution between the insects and plants (Mello and SilvaFilho, 2002). Hundreds of plant species have been studied in order to find out the active ingredients responsible for their insecticidal activity against various pests of economic significance. Among the insecticidal plants, Meliaceae,

\footnotetext{
* Author for correspondence: lubarbosabio@hotmail.com
} 
Rutaceae, Asteraceae, Labiateae, Piperaceae and Annonaceae are more frequently cited for presenting a broad spectrum of action in relation to both the number of affected insect species and their different modes of action (Akhtar and Isman, 2004). There are not many works available in the literature on the insecticidal activity of Euphorbiaceae species, which present diverse biological activities.

Cis-dehydrocrotonin extracted from Croton cajucara bark inhibits the growth of Heliothis virescens (Lepidoptera) (Viegas-Junior, 2003). Jatropha curcas (Euphorbiaceae), known for its insecticidal properties, affects the insects of various families, and its ingestion inhibits the growth of several Lepidoptera species (Sauerwein et al., 1993). Its contact toxicity was described by Solsoloy (1993). The methanolic extract from $J$. curcas has insecticidal activity against Helicoverpa armigera (Lepidoptera) and Sitophilus zeamais (Coleoptera) (Solsoloy, 1995), and Culex quinquefasciatus (Diptera) (Karmegam et al., 1997).

Although innumerous species of the genus Croton (Euphorbiaceae) present several biological activities (Peres et al.,1997 and 1998; Suárez et al., 2003; Anazetti et al., 2004; Fisher et al., 2004), there are no reports for Croton urucurana on insecticidal, deterrent, repellent activities or inhibiting action on insects' digestive enzymes.

Anagasta kuehniella (Zeller) (Lepidoptera: Pyralidae), popularly known as Mediterranean flour moth is found worldwide, particularly in the stored grains as a flour and grain feeder: it is often a severe pest in flour mills. Controlling these insects generally requires the use of chemical insecticides that are toxic to the humans and domestic animals and harmful to the environment. Considering the advancement of researches on the botanical insecticides and their potential for pest control, the objective of this work was to evaluate, under laboratory conditions, the bioactivity of methanolic extract, semipurified fractions and crude resin of Croton urucurana Baillon, 1864 (Euphorbiaceae), against Anagasta kuehniella Zeller, 1879 (Lepidoptera: Pyralidae).

\section{MATERIALS AND METHODS}

\section{Botanical material and methanolic extract and semipurified fractions preparations}

Husk of stem and crude resin of $C$. urucurana were collected in May 1994, in the region of Dourados, Mato Grosso do Sul, Brazil. The species was identified by Claudio Conceição, Biology Department, Federal University of Mato Grosso do Sul-UFMS, Campo Grande -MS, and a sample has been deposited (no. 5009) at CGMS Herbarium .

Husk of stem, dried at room temperature and ground, was extracted with methanol. After methanol evaporation in a rotavapor, a solid brown-reddish material, named methanol extract $(\mathrm{EMeOH})$ was obtained. Afterward, the material was percolated on a silica gel $60(200 \mathrm{~g})$ column, using hexane, dichloromethane and ethyl acetate successively. This resulted three semipurified fractions, hexane $(\mathrm{FH})$, dichloromethane $(\mathrm{FDM})$ and ethyl acetate (FAE). Crude resin was collected directly from the trunk.

\section{Insect Biossays}

Colonies of A. kuehniella were maintained at the Protein Purification and Biological Function Laboratory (LPPFB), Department of Natural Sciences - UFMS, 'Três Lagoas' Campus - MS.

To evaluate the effects of $\mathrm{EMeOH}$, FDM, FAE and crude resin of $C$. urucurana on A. kuehniella larval development, the moths were kept in plastic boxes, with perforated plastic covers at $28 \pm 1{ }^{\circ} \mathrm{C}$, $65-77 \%$ relative humidity, with a $16-\mathrm{h}$ photophase. An artificial diet of A. kuehniella was prepared by mixing the whole-wheat flour, wheat germ and wheat bran $(8: 1: 1)$, three concetrations $(0.5,1.0$ and $2.0 \%$ ) of $\mathrm{EMeOH}$, and $2.0 \%$ of FDM, FAE and crude resin each. A control meal was also prepared without the addition of $\mathrm{EMeOH}$, FDM, FAE and crude resin. Treatments were repeated 16 times with five neonate larvae $(\mathrm{n}=80)$ per concentration. After four instars, the weight and larval survival were recorded.

The analyzed biological and biochemical parameters were weight and larval mortality, pupal and larval stages, pupal weight and pupal morphological imperfections, sex ratio, adult emergence and enzymatic activity of fourth instar larvae. 


\section{Midgut homogenate preparation}

Larval gut homogenates were prepared according to Macedo et. al., (1993). Fourth instar larvae were cold immobilized in $250 \mathrm{mM} \mathrm{NaCl}$ and dissected. Larval midguts were surgically removed using tweezers. Only actively feeding larvae with guts filled with food were used. The gut portion posterior to the proventriculus and anterior to the malpighian tubules was taken. After removing all the extraneous tissue and freeing the lumen from its contents by rinsing in $0.05 \mathrm{M}$ Tris $/ \mathrm{HCl}$ buffer (pH 8.0), midgut tissues were homogenized, centrifuged at $17,000 \mathrm{rpm}$ for 20 minutes at $4^{\circ} \mathrm{C}$, and the supernatants were collected in a known volume of appropriate buffer and immediately used as enzymes sources for enzymatic assays.

The protein concentration in the extract was determined according to Bradford (1976).

\section{Protease activity assay}

The total tryptic activity was determined using BAPNA (N-benzoyl-D,L-arginine- $\rho$-nitroanilide) as substrate. Midgut and excrements extract $(50 \mu \mathrm{g}$ of protein) were incubated in $0.05 \mathrm{M}$ Tris $-\mathrm{HCl}$ buffer ( $\mathrm{pH} 8.0)$, to a final volume of $500 \mu \mathrm{L}$ for 10 min before the addition of $1 \mathrm{~mL}$ BAPNA substrate. The reaction was allowed to proceed at $37^{\circ} \mathrm{C}$ for $20 \mathrm{~min}$ then stopped by adding $30 \%$ acetic acid $(\mathrm{v} / \mathrm{v})$. The resulting absorbance was read at $410 \mathrm{~nm}$. One enzyme unit was defined as the amount of protein that catalyzed the cleavage of $1 \mu \mathrm{mol}$ substrate/min.

Chymotryptic activity was determined using SAAP (N succinyl ALA-ALA-PRO-PHE pNitranilide) as substrate. Midgut and excrements extract $(50 \mu \mathrm{g}$ of protein) were incubated in $0.1 \mathrm{M}$ Tris-HCl buffer ( $\mathrm{pH} 8.0$ ), to a final volume of $500 \mu \mathrm{L}$ for $10 \mathrm{~min}$ before the addition of $1 \mathrm{~mL}$ SAAP substrate dissolved in pure DMSO (dimethylsufoxide). The reaction was allowed to proceed at $37^{\circ} \mathrm{C}$ for $20 \mathrm{~min}$, then stopped by adding $30 \%$ acetic acid $(\mathrm{v} / \mathrm{v})$. The resulting absorbance was read at $405 \mathrm{~nm}$. One enzyme unit was defined as the amount of protein that catalyzed the cleavage of $1 \mu \mathrm{mol}$ substrate/min.
Polyacrylamide gel eletrophoresis

SDS polyacrylamide gel (10\%) electrophoresis (SDS-PAGE) was performed as described by Laemmli (1990). Proteins were detected by staining with $0.25 \%$ Coomassie brilliant blue R250.

\section{Nutritional Indexes}

Food ingestion and utilization by the insects was determined according to Parra (1991).

\section{Statistical Analysis}

The data were examined using a one-way analysis of variance (ANOVA). The Tukey's test was used to indicate the means significantly different, $p$ $<0.05$.

\section{RESULTS}

\section{Development of A. kuehniella larvae}

The effect of $C$. urucurana methanol extract $(\mathrm{EMeOH})$, crude resin, dichloromethane (FDM) and ethyl acetate (FAE) fractions incorporated to the artificial diet on the development of $A$. kuehniella was assessed by determining the number and weight of surviving fourth instar larvae.

The number and weight of surviving A. kuehniella larvae fed artificial diet with $0.5,1.0$ and $2.0 \%$ $\mathrm{EMeOH}$ (Fig. $1 \mathrm{~A} ; \mathrm{B})$ and $2.0 \%$ crude resin of $C$. urucurana (Fig. 1 C;D) did not differ from the control.

The dose response effect of FAE on the mortality of larvae is shown in figure $1 \mathrm{G}$. The artificial diet containing 2.0, 1.0 and $0.5 \%$ FAE caused 100, 55 and $68 \%$ mortality, respectively (Fig. $1 \mathrm{H}$ ) when compared with the control. Larvae fed on 1.0 and $0.5 \%$ FAE had 30 and $54 \%$ decrease in weight respectively. With FDM, the mortality and weight of A. Kuenhiella larvae feeding on control diet were $25 \%$ and $6 \mathrm{mg}$, respectively, while a diet containing $2.0 \%$ FDM produced an estimated $65 \%$ mortality and a 30\% decrease in weight (Fig. $1 \mathrm{E} ; \mathrm{F})$. 

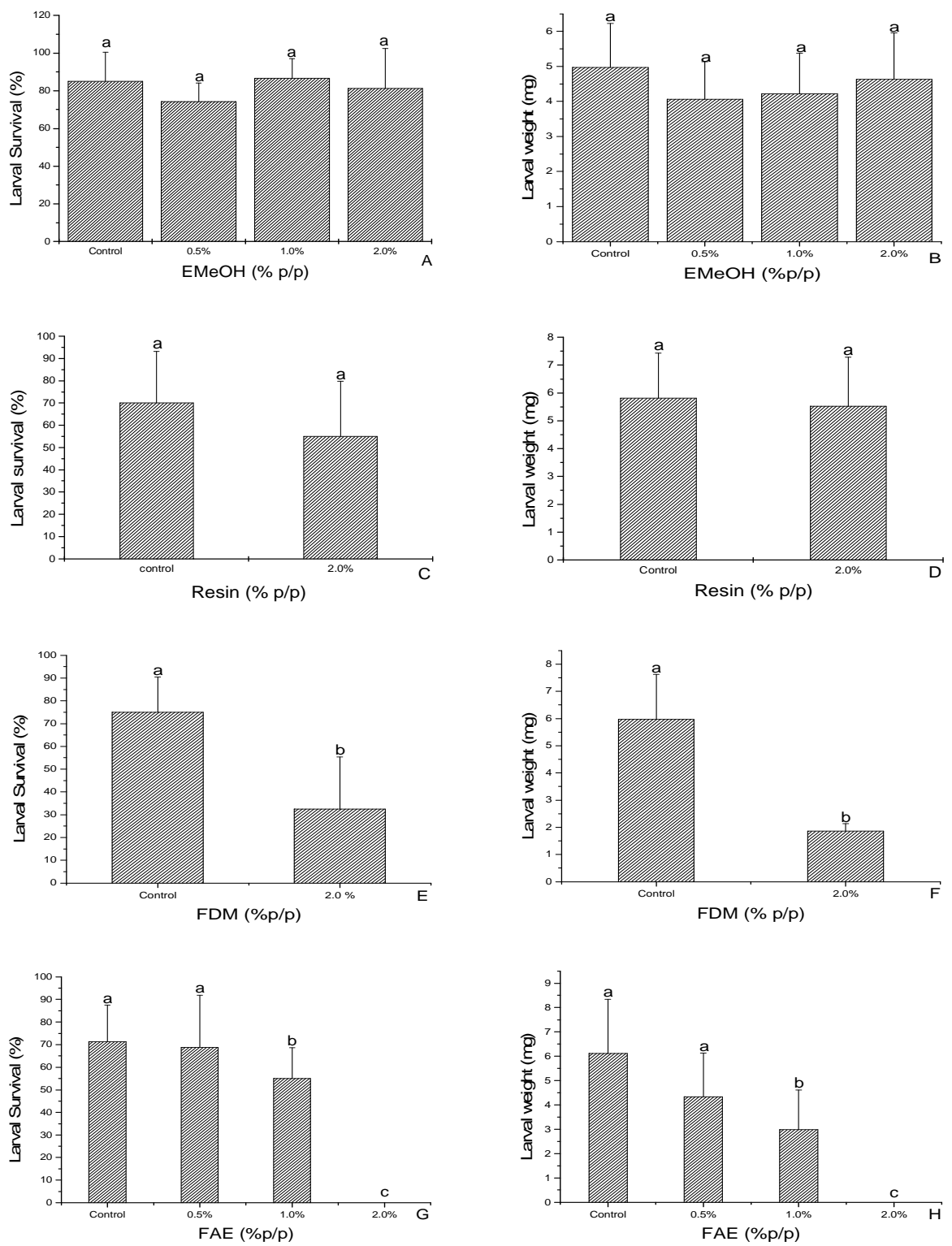

Figure 1 - Larval survival and weight of fourth-instar A. kuehniella larvae fed at control and artificial diets containing EMeOH $(\mathbf{A} ; \mathbf{B})$, crude resin $(\mathbf{C} ; \mathbf{D})$, FDM $(\mathbf{E} ; \mathbf{F})$ and FAE $(\mathbf{G} ; \mathbf{H})$. Bar with the same letter are not significantly different by the Tukey's test at 5 $\%$ probability.

\section{Nutritional Indexes for A. kuehniella}

The results showed no significant differences for the amount of food ingested and excrements produced, comparing larvae fed with control diet to those fed $\mathrm{EMeOH}$ (Fig. $2 \mathrm{~A} ; \mathrm{B}$ ) and crude resin (Fig. $2 \mathrm{C}$;D). There was no reduction in the efficiency of conversion of ingested food (ECI) or in the efficiency of conversion of digested food (ECD) for the larvae fed $\mathrm{EMeOH}$ and crude resin compared with the control. The metabolic cost was not significantly altered in relation to the control (Table 1).

Approximate digestibility (AD), which represented the percentage of ingested food that was effectively assimilated by the insect, was not significantly different (Table 1).

Figure 2 (E;F) showed that with the diet containing FDM food ingestion and excrements produced were reduced, with lower insect weight gain. 
The lowest efficiencies of conversion of ingested (ECI) and digested (ECD) food were found in larvae fed the diet containing FDM (2\%) and FAE (1\%) (Table 1), representing a reduction of approximately $60 \%$ and consequently the metabolic cost was $40 \%$ higher for the insects fed with these diet. As seen in Table 1, the approximate digestibility (AD) was about $23 \%$ higher for the insects fed with the diet containing FDM and FAE, when compared with the control.
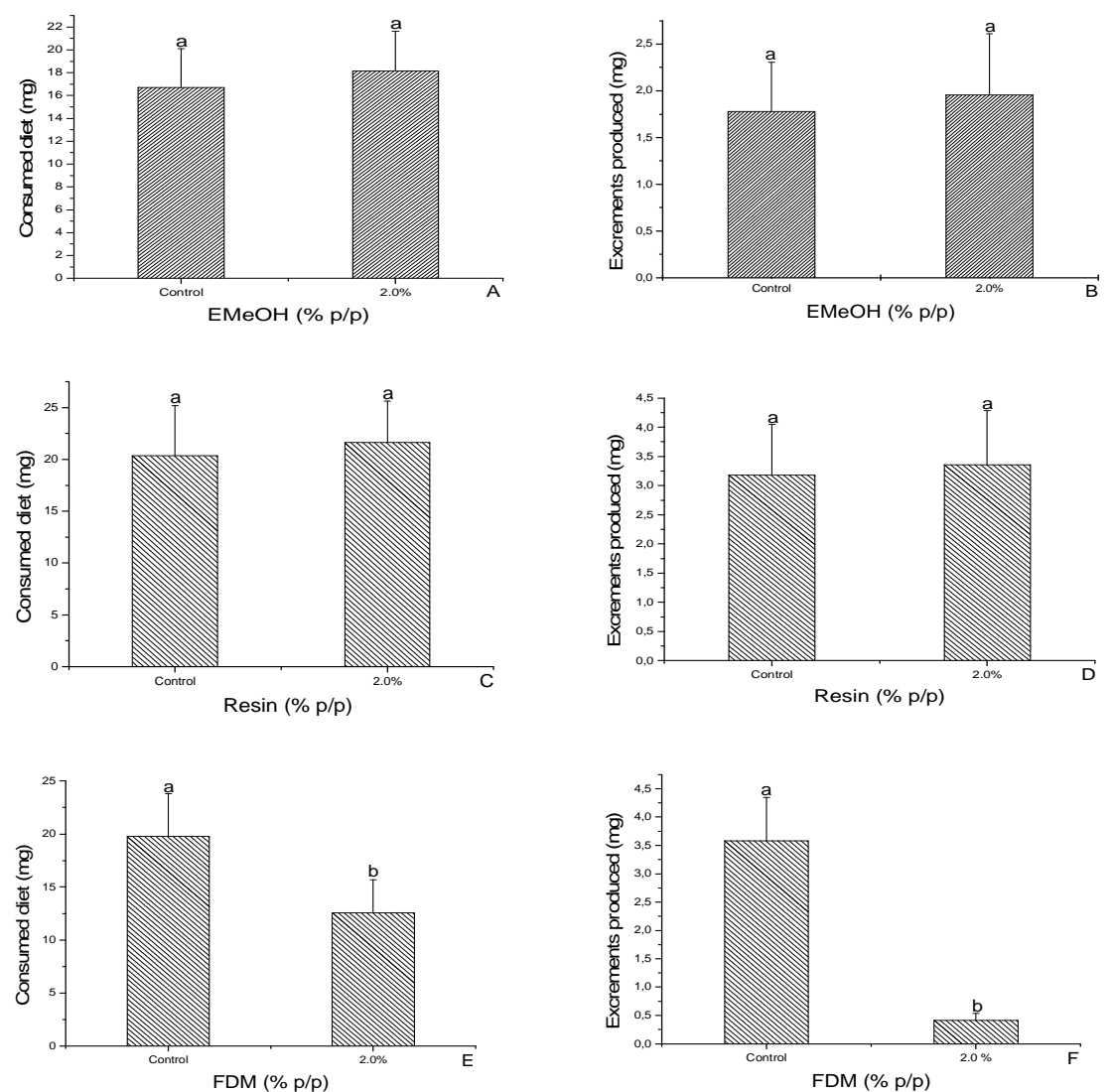

Figure 2 - Diet ingested and excrements produced by fourth-instar A. kuehniella larvae fed control diet and artificial diet containing $\operatorname{EMeOH}(\mathbf{A} ; \mathbf{B})$, crude resin $(\mathbf{C} ; \mathbf{D})$ and FDM $(\mathbf{E} ; \mathbf{F})$. Bar with the same letter are not significantly different by the Tukey's test at $5 \%$ probability.

Table 1 - Efficiency of conversion of ingested (ECI) and digested (ECD) food, approximate digestibility (AD) and metabolic cost (CM) of A. kuenhiella larvae fed control diet and artificial diet with $2.0 \% \mathrm{EMeOH}, 2.0 \%$ crude resin of C. Urucurana, 2.0\% FDM and 1.\% FAE.

\begin{tabular}{cccccc}
\hline Nutritional Indexes & Control & EMeOH & Crude Resin & FDM & FAE \\
\hline ECI & $27.7 \pm 3.9 \mathrm{a}$ & $23.42 \pm 4.7 \mathrm{a}$ & $25 \pm 5.2 \mathrm{a}$ & $11.7 \pm 6.0 \mathrm{~b}$ & $12.3 \pm 8.5 \mathrm{~b}$ \\
ECD & $33 \pm 6.5 \mathrm{a}$ & $26.56 \pm 6.1 \mathrm{a}$ & $30 \pm 6.9 \mathrm{a}$ & $12 \pm 7.3 \mathrm{~b}$ & $13.4 \pm 9.3 \mathrm{~b}$ \\
AD & $86 \pm 8.5 \mathrm{a}$ & $88.21 \pm 3.3 \mathrm{a}$ & $84 \pm 3.7 \mathrm{a}$ & $95 \pm 3.1 \mathrm{~b}$ & $93.7 \pm 8.1 \mathrm{~b}$ \\
CM & $65 \pm 6.5 \mathrm{a}$ & $73.43 \pm 6.1 \mathrm{a}$ & $69 \pm 6.9 \mathrm{a}$ & $87 \pm 7.3 \mathrm{~b}$ & $83.2 \pm 8.3 \mathrm{~b}$ \\
\hline
\end{tabular}

Values followed by the same letter within a row are not significantly different by the Tukey's test at $5 \%$ probability. 
Duration of larval stage, pupa weight, duration of pupal stage, adult emergence and sex ratio There were no significant differences for the treatments with $\mathrm{EMeOH}$ and crude resin of $C$. urucurana for the duration of the larval stage. Neither $\mathrm{EMeOH}$ nor crude resin reduced the larval viability of A. kuehniella (Table 2).

The average pupa weights were $19 \mathrm{mg}$ for the control and $18 \mathrm{mg}$ for the treatments. The results for pupal viability showed no significant differences between the control and the treatments with $\mathrm{EMeOH}$ and crude resin (Table 2).

The number of adult A. kuehniella emerging after two months from the artificial diet containing $\mathrm{EMeOH}$ and $2.0 \%$ crude resin did not differ from the number of adults from the control, and the viability was on average $72 \%$ of the 50 initial larvae. The sex ratio was similar for both the control and treatments.

Table 2 - Duration and viability of larval and pupal stages and pupa weight of A. kehniella fed with control diet and artificial diet containing $2.0 \% \mathrm{EMeOH}$ and $2.0 \%$ crude resin $(\mathrm{n}=50)$ of $C$. urucurana.

\begin{tabular}{cccccc}
\hline & Larval stage & \multicolumn{3}{c}{ Pupal stage } \\
\hline Concentration (\%) & Duration day & Viability(\%) & Duration day & Viability(\%) & Pupa weight (mg) \\
\hline Control & $36.8 \pm 4.0 \mathrm{a}$ & $88 \mathrm{a}$ & $8.7 \pm 1.1 \mathrm{a}$ & $84 \mathrm{a}$ & $19.2 \pm 1.8 \mathrm{a}$ \\
$\mathrm{EMeOH} 2,0 \%$ & $38.4 \pm 4.7 \mathrm{a}$ & $90 \mathrm{a}$ & $8.6 \pm 1.2 \mathrm{a}$ & $88 \mathrm{a}$ & $17.6 \pm 1.8 \mathrm{a}$ \\
Resin 2,0\% & $36 \pm 2.8 \mathrm{a}$ & $80 \mathrm{a}$ & $9.0 \pm 0.2 \mathrm{a}$ & $83 \mathrm{a}$ & $18 \pm 1.2 \mathrm{a}$ \\
\hline
\end{tabular}

Values followed by the same letter within a row are not significantly different by the Tukey's test at $5 \%$ probability.

\section{Effects of EMeOH, Crude Resin and FAE on proteolytic activity}

Tryptic and chymotryptic activities of $A$. kuehniella larvae with $\mathrm{EMeOH}$., crude resin and FAE of $C$. urucurana, were analyzed through the hydrolysis of BAPNA and SAAP, respectively.

No significant differences were found for the tryptic activity of midguts and excrements in larvae of C. urucurana fed $\mathrm{EMeOH}$ (Fig. $3 \mathrm{~A} ; \mathrm{B}$ ) and larvae receiving the artificial diet with crude resin (Fig. $4 \mathrm{~A} ; \mathrm{B}$ ), when compared with the control.

The tryptic activity of the midgut fluid and excrements of larvae fed $2.0 \%$ FAE (Fig. 5 A) was reduced by $78.5 \%$ and the assays with the excrements homogenate decreased $56.5 \%$ when compared with the control (Fig. 5 B).

The chymotryptic activity in the midguts of the larvae fed the diet containing EMeOH (Fig. $3 \mathrm{C} ; \mathrm{D}$ ) and crude resin (Fig. $4 \mathrm{C} ; \mathrm{D}$ ) was similar to that found in the larvae fed the control diet.
However, the chymotryptic assays carried out with the midgut fluid homogenate of larvae fed FAE demonstrated a reduction in the enzyme activity (Fig. 5 C;D).

The eletrophoresis confirmed the data obtained from the midgut triptic activity, in which the larvae treated with $\mathrm{EMeOH}$ (Fig. 6 I) and crude resin (Fig. 6 II) presented proteolytic activity similar to the control. The fecal material did not allow the protein bands, corresponding to the enzymes to be well defined (data not shown).

The electrophoresis of gut enzyme activity, confirmed the results obtained for the triptic activity, in which the insects treated with FAE showed a lower trypsin-like proteolytic activity (Fig. 6 III).

The eletrophoresis also showed that the insects treated with $\mathrm{EMeOH}$, crude resin and FAE (Fig.6 I, II and III) presented trypsin-like proteolytic activity; the proteolytic bands were inhibited by $N$ tosyl-L-lysine chloromethyl ketone (TLCK), confirming their tryptic activity. 


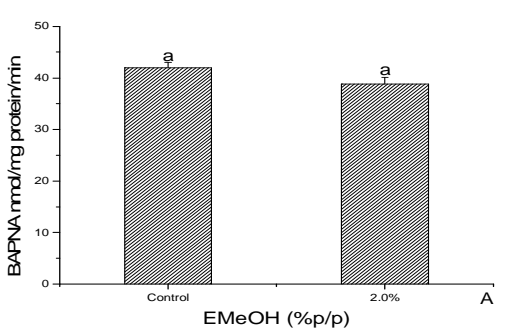

Tryptic IM

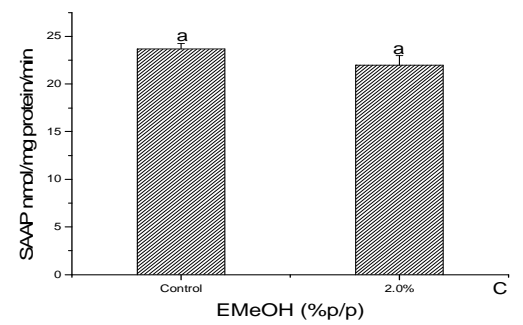

Chymotryptic IM

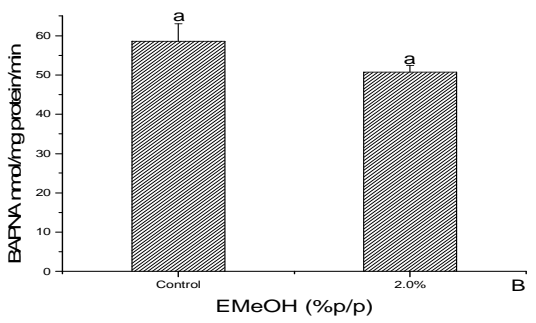

Tryptic excrements

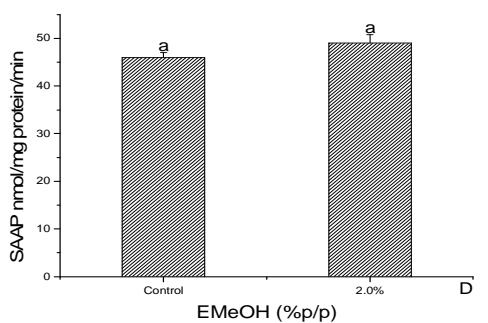

Chymotryptic excrements

Figure 3 - Tryptic and chymotryptic activity of the midgut fluid and excrements of A. kuehniella fourth-instar larvae fed control diet and artificial diet containing EMeOH. Same letters are not significantly different by the Tukey's test at $5 \%$ probability.

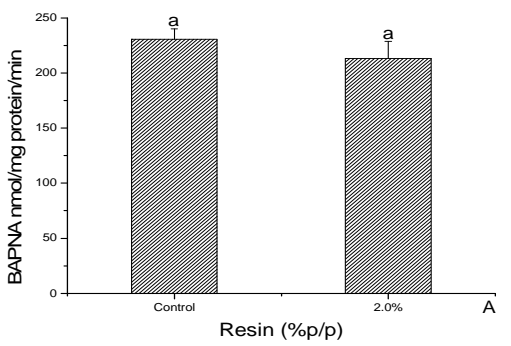

Tryptic IM

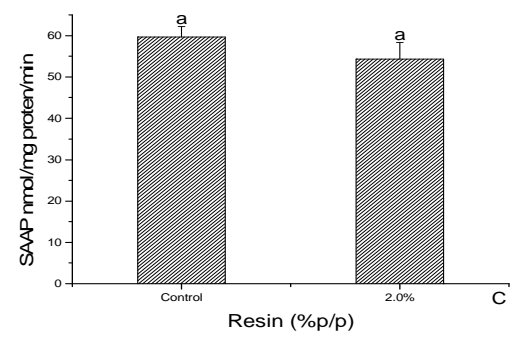

Chymotryptic IM

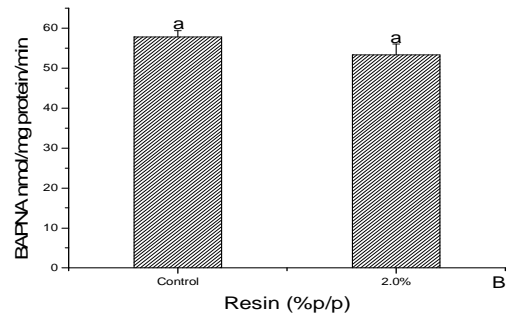

Tryptic excrements

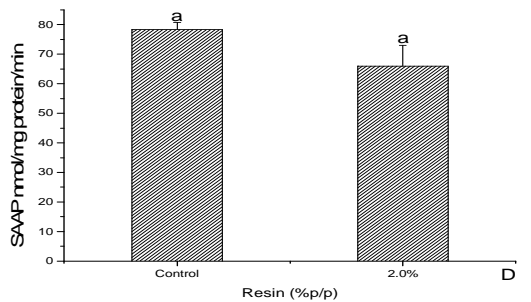

Chymotryptic excrements

Figure 4 - Tryptic and chymotryptic activity of midgut fluid and excrements of A. kuehniella fourth-instar larvae fed control diet and artificial diet containing crude resin. Bar with the same letter are not significantly different by the Tukey's test at $5 \%$ probability. 


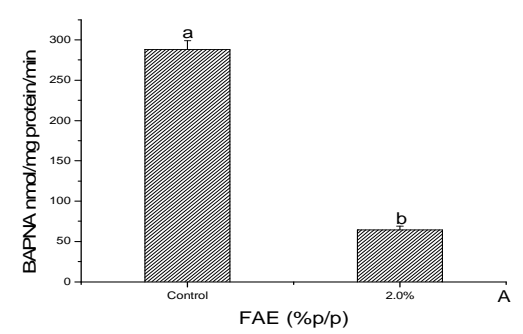

Tryptic IM

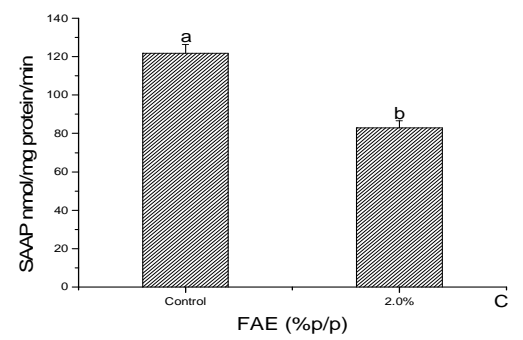

Chymotryptic IM

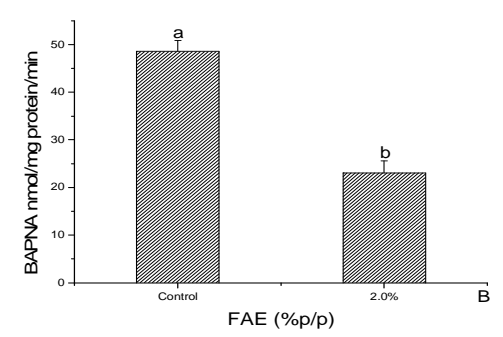

Tryptic excrements

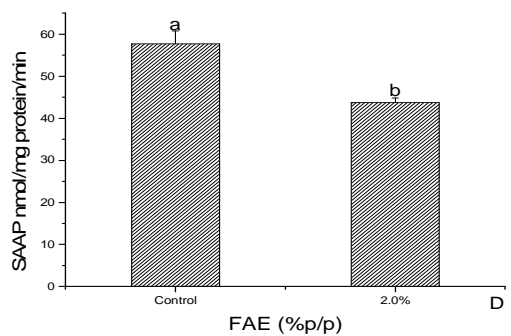

Chymotryptic excrements

Figure 5 - Tryptic and chymotryptic activity of midgut fluid and excrements of A. kuehniella fourth-instar larvae fed control diet and artificial diet containing FAE. Bar with the same letter are not significantly different by the Tukey's test at $5 \%$ probability.
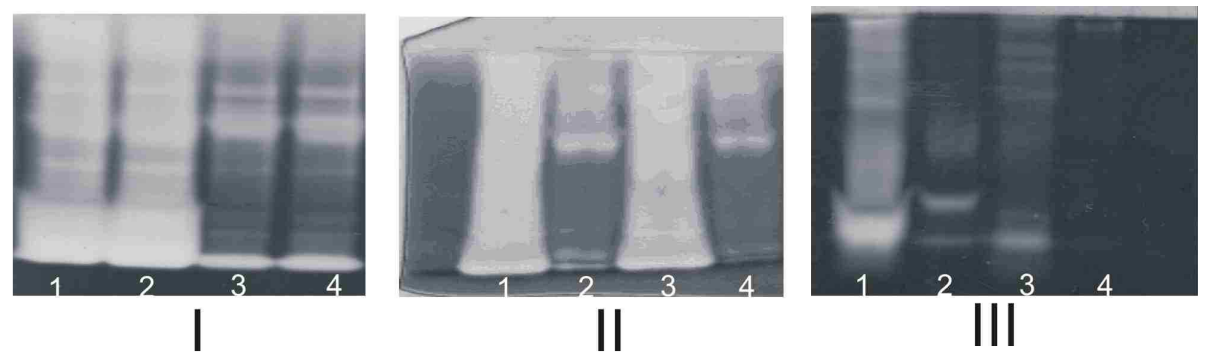

Figure 6 - Responses of A. kuehniella to $\mathrm{EMeOH}$, Crude Resin and AE ingestion. Proteinase assays after SDS-PAGE: (I) $2.0 \% \mathrm{EMeOH}$ 1-IM control, 2-IM 2.0\% EMeOH, 3-IM control+TLCK, 4-IM 2.0\% EMeOH +TLCK. (II) crude resin. 1-IM control, 2- IM control+TLCK, 3-IM 2.0\% resin, 4-IM 2.0\% resin +TLCK. (III) FAE. 1-IM control, 2- IM control+TLCK, 3-IM 1.0\% FAE, 4-IM 1.0\% FAE +TLCK.

\section{DISCUSSION}

The use of plants with insecticidal activity has gained importance over the past few years. Though their utilization is not a novelty, it has been rather common before inorganic insecticides became available. The resurgence as a method of insect control is based on the current demand for the molecules that are useful in pest management without contaminating the environment or remaining as residues in the foods.
The selection of $C$. urucuran, was based on the popular information, its bactericidal activity and chemical studies (Peres et al., 1997, 998). The present work verified the toxicity of $C$. urucurana methanolic extract, semipurified fractions and crude resin on the development of A. kuehniella. The semipurified FDM and FAE fractions caused expressive mortality to A. kuehniella larvae, especially FAE (2.0\%), reaching $100 \%$ mortality rate. Previous chemical studies on this fraction resulted in the isolation of the phenolic compounds 
catechin and gallocatechin, which played a role in the insecticidal activity (Peres et al., 1998).

According to Shirley (2001) condensed tannins, catechin and gallocatechin are phenolic compounds responsible for the astringency of many fruits as well as defense against the pests, as they attach to insects' digestive proteins, becoming an important mechanism for the plant defense against the pathogens (Oliveira et al.,2003). This ability of tannins to interact with the proteins makes this class of substances rather toxic elements to insects, fungi and bacteria.

Studies using histological sections have demonstrated the toxic effect of tannic acid, a hydrolyzable natural tannin on the midgut epitelium of Diptera larvae (Rey et al., 1999). Other investigators, after evaluating the toxic effects of tannins on the fauna associated with Culicidae, suggested that the vegetable tannins can be useful as a complement in control programs of hematophagous species of mosquitoes associated with the human diseases. Studies carried out with the extracts of Magonia pubescens (Sapindaceae) provided evidence that the action mechanisms and morphological changes leading to the death in $A$. aegypti were similar to those of tannic acid (Arruda et al., 2003; Pautou et al., 2000; Silva et al., 2003).

Moreover, toxicological studies performed in the rabbits, mice and guinea pigs have proved to be atoxic, according to the rules for plant products. Field tests have confirmed their degradation and atoxicity from the fourth week onward (Silva et al., 2003).

Despite these favorable features, additional toxicological studies on catechinic tannins must be carried out in order to evaluate their impacts, mainly on non-target species, and to identify the formulations that provided stability and easiness of management (Silva et al., 2004).

For the FDM fraction (2.0\%), chemical studies led to the isolation of terpenoid compounds (Peres et al., 1998). The $65 \%$ mortality rate found for $A$. kuehniella larvae fed on FDM diet may have been caused by diterpenes, such as 12-epimethylbarbascoate, isolated from this fraction. The chemical class of diterpenes has already been reported as having insecticidal activity (Mancebo et al., 2002; Medina, et al.,2003; Breuer, et al., 2003; Akhtar and Isman, 2004; Boeke et al., 2004).

The use of plants that affect the insect larval development is quite advantageous because when life is interrupted at this stage, there is a reduction in the insect population during the period in which grain damage is being caused (Hernández andVendramim, 1996). The losses caused by the pest attacks during grain storage can reach up to 10\% (Obeng-Ofori and Amiteye, 2005).

Lower efficiency of conversion of ingested and digested food was found for the insects fed FDM $(2 \%)$ and FAE (1\%) diet, which meant that in these diets, a smaller quantity of the food (energy) was used to produce the insect biomass. It was likely that in these fractions, a larger amount of metabolic energy was used for the degradation of toxins. This was confirmed by comparing the metabolic costs, which were higher for the larvae fed on FDM and FAE diet. The approximate digestibility was also higher for the larvae fed on FDM and FAE diet, indicating differential activity of the digestive enzymes, therefore the need for the food to remain in the insect's digestive tract for a longer period of time in order to allow the degradation of the secondary compounds of this fraction (Hernández and Vendramim, 1996). According to the same authors, the inverse correlation between the $\mathrm{AD}$ and $\mathrm{ECD}$ values was probably because when digestibility was high, there was a proportional higher expenditure of digested food on the metabolic energy, which resulted in a lower biomass gain per unit of digested food, corresponding to ECD.

Nathan et al. (2005) reported that limonoids from Azadiracta indica A. Juss (azadirachtin, salannin, and acetylgedunin, gedunin), the main representatives of the terpernoid class with insecticidal activity, have significant effect on the larvae and pupae of Cnaphalocrocis medinalis (Lepidoptera: Pyralidae), causing weight loss and reduction of enzymatic activity. The adult physiology is harmed when the larva is exposed to the limonoids present in this meliaceae.

The methanol $(\mathrm{EMeOH})$ extract and crude resin of C. urucurana incorporated into the artificial diet did not interfere with the weight or with the survival of A. Kuehniella larvae. The larvae that survived $\mathrm{EMeOH}$ and crude resin turned into pupae normally, and the pupae derived from these larvae had no significant differences in weight or morphological changes, which demonstrated that the larvae were, to a certain extent, able to overcome the toxic action of substances present either in $\mathrm{EMeOH}$ or in the crude resin incorporated in the diet. 
The tryptic and chymotryptic assays showed no effect that could impair the development of the insects fed on diet with $\mathrm{EMeOH}$ or crude resin.

The tryptic and chymotryptic activities performed with the midgut fluid and excrements presented a significant reduction for the larvae treated with FAE, when compared with the control. Comparing the results of larval weight, it was observed that the significant reduction in the tryptic and chymotryptic activity could have reflected on insect physiological misfit, since the larvae of this treatment had a reduction of about $30 \%$ in weight.

Trypsin was present in all the degradation products from insects subjected to $\mathrm{EMeOH}$ and crude resin, as band intensity was reduced in the presence of TLCK.

The eletrophoresis of the midgut homogenates from the control larvae and the larvae treated with $\mathrm{EMeOH}$ and crude resin showed that there were no changes in the pattern of digestion products of the treated larvae compared to the control.

The results demonstrated the importance of the bioassay-guided isolation research. As shown in the present work, the biological activity was evaluated through the biological and biochemical parameters of the crude methanolic extract, semipurified fractions (Ethyl acetate and Dichloromethane) and crude resin of $C$. urucurana. Although there have been innumerous reports on the insecticidal potential of plants against Lepidoptera, few works used A. kuehniella (Macedo et al., 2003 and 2004 a and b; Warchalewski et al., 2002) as model, and no report was found on the insecticidal activity of $C$. urucurana.

Elucidation of the mechanism of action of the extracts and other compounds derived from the plants in the insects of economic importance, and the mechanism that insects developed in order to survive the toxic action of substances present in the diet, would be useful for discovery and synthesis of new insecticidal molecules. Knowledge of the chemical composition of the plant secondary metabolites and their respective biological activities would contribute to an integrated pest management. More studies with purified compounds to determine their mechanism of action are required.

\section{ACKNOWLEDGEMENTS}

The authors would like to thank UFMS/PROPP and CAPES, FINEP, CNPq and FUNDECT for the financial support.

\section{RESUMO}

Atualmente centenas de plantas são investigadas para se conhecer os princípios ativos responsáveis pela atividade inseticida contra as diversas pragas de importância econômica. Com o objetivo de verificar a atividade inseticida das cascas do caule de Croton urucurana Baillon 1864 (Euphorbiaceae) em relação a Anagasta kuehniella Zeller 1879 (Lepidoptera: Pyralidae), avaliou-se o extrato metanólico $(\mathrm{EMeOH}), \quad$ fração diclorometano (FDM), a fração acetato de etila (FAE) e a resina in natura, os quais foram adicionados à dieta artificial. $\mathrm{O} \mathrm{EMeOH}(0,5,1,0 \mathrm{e}$ $20, \%)$ e a resina in natura $(2,0 \%)$, não interferiram no peso, sobrevivência das larvas de $4^{\text {a }}$ ínstar, bem como nos demais parâmetros analisados. A fração FDM $(2,0 \%)$ causou mortalidade de $65 \%$, e a dieta artificial contendo 2,0, 1,0, e 0,5\% de FAE causou 100,55 e $68 \%$ de mortalidade respectivamente quando comparado com o controle, constatando-se as menores eficiências de conversão do alimento para a FDM $(2,0 \%)$ e FAE $(1,0 \%)$. Através do ensaio tríptico realizado com o fluido do intestino médio das larvas, foi possível verificar que a atividade tríptica e quimiotríptica para as larvas alimentadas com dieta artificial contendo o $\mathrm{EMeOH}$ e a resina in natura não apresentaram diferenças significativas.

\section{REFERENCES}

Akhtar, Y.; Isman, M. B. (2004), Comparative growth inhibitory and antifeedant effects of plant extracts and pure allelochemicals on four phytophagous insect species. Journal of Applied Entomology 128, 32-38.

Anazetti, M. C.; Melo, P. S.; Durán, N.; Hauna, M. (2004). Dehydrocrotonin and its derivative, dimethylamide-crotonin induce apoptosis with lipid peroxidation and activation of caspases-2, -6 and -9 in human leukemic cells HL60. Toxicology 15, 123137. 
Arruda W, Oliveira G. M. C, Silva I. G. (2003), Toxicidade do extrato etanólico de Magonia pubescens sobre larvas de Aedes aegypti. Revista da Sociedade Brasileira de Medicina Tropical 36, 17-25.

Boeke, S. J.; Baumgart, I. R.; Van Loon, J. J. A.; Van Huis, A.; Dicke, M.; Kossou, D. K. (2004), Toxicity and repellence of African plants traditionally used for the protection of stored cowpea against Callosobruchus maculates. Journal of Stored Products Research 40, 423-438.

Bradford, M. M., (1976), A rapid and sensitive method for the quantification of microgram quantities of protein utilizing the principe of protein dye binding. Annual Biochemistry 72, 248-254.

Breuer, M.; Hoste, B.; De Loof, A.; Naqvi, S. N. H. (2003), Effect of Melia azedarach extract on the activity of NADPH-cytochrome reductase and cholinesterase in insects. Pesticide Biochemistry and Physiology 76, 99-103.

Carlini, C. R.; Grossi-de-Sá, M. F. (2002), Plant toxic proteins with insecticidal properties. A review on their potentialities as bioinsecticides. Toxicon 40, 1515-1539.

Fischer, H.; Machen, T. E.; Widdicombe, J. H.; Carlson, T. J. S.; King, S. R.; Chow, J. W. S. Illek, B. (2004), A novel extract SB-300 from the stem bark latex of Croton lechleri inhibits CFTR-mediated chloride secretion in human colonic epithelial cells. Journal of Ethnopharmacology 93, 351-357.

Hernández, R. C.; Vendramim, J. D. (1996), Toxicidade de extrato aquoso de Meliaceae em Spodoptera frugiperda (Lepidoptera: Noctuidae). Manejo Integrado de Plagas 42, 14-22.

Karmegam N.; Sakthivadivel M.; Anuradha V.; Thilagavathy D. (1997), Indigenous-plant extracts as larvicidal agents against Culex quinquefasciatus Say. Bioresource Technology 59, 137140.

Laemmli, U. K. (1990), Clevage of structural during the assembly of the head of bacteriophage T4. Nature 227, 680-685.

Macedo, M. L. R.; Fernandes, K. V. S., Sales, M. P., Xavier-Filho, J. (1993), Vicillins variants and the resistance of cowpea (Vigna unuiculata) Seeds to the cowpea weevil (Callosobruchus maculatus). Comparative Biochemistry Physiology C 105, 89-94.

Macedo, M. L. R.; Freire, M. G. M.; Cabrini, E. C.; Toyama, M. H.; Novello, J.C.; Marangoni, S. (2003), A trypsin inhibitor from Peltophorum dubium seeds active against pest proteases and its effect on the survival of Anagasta kuehniella (Lepidoptera: Pyralidae). Biochimica et Biophysica Acta 1621, 170- 182.

Macedo, M. L. R.; Castro, M. M.; Freire, M. G. M. (2004a), Mechanisms of the insecticidal action of TEL (Talisia eculenta Lectin) against Callosobruchus maculatus (Coleoptera: Bruchidae). Archives of Insect Biochemistry and Physiology 56, 84-96.
Macedo, M.L.R.; De Sa, C.M.; Freire, M.D.G. M.; Parra, J. R. P. (2004b), A Kunitz-type inhibitor of coleopteran proteases, isolated from Adenanthera pavonina L. seeds and its effect on Callosobruchus maculatus. Journal Agricultural Food Chemistry 52, 2533-2540.

Mancebo, F.; Hilje, L.; Mora, G. A.; Salazar, R. (2002), Biological activity of two neem (Azadirachta indica A. Juss., Meliaceae) products on Hypsipyla grandella (Lepidoptera: Pyralidae) larvae. Crop Protection 21, 107-112.

Medina, P.; Smagghe, G.; Budia, F.; Tirry, L.; Vinuela, E. (2003), Toxicity and absorption of azadirachtin, diflubenzuron, pyriproxyfen, and tebufenozide after topical apllication in predatory Larvae of Chrysoperla carnea (Neuroptera: Chrysopidae). Environmental Entomology 32,196-203.

Mello, M. O; Silva-Filho, M. C. (2002), Plant-insect interactions: an evolutionary arms race between two distinct defense mechanisms. Brazilian Journal of Plant Physiology 14, 71-81.

Montesdeoca, M.; Lobo, M. G.; Casañas, N.; Carnero, A.; Castañera, P.; Ortego, F. (2005), Partial characterization of the proteolytic enzymes in the gut of the banana weevil, Cosmopolites sordidus, and effects of soybean Kunitz trypsin inhibitor on larval performance. Entomologia Experimentalis et Applicata 116, 227-236.

Nathan, S. S.; Kalaivani, K.; Murugan, K.; Chung. P. G. (2005), The toxicity and physiological effect of neem limonoids on Cnaphalocrocis medinalis (Guenée) the rice leaffolder. Pesticide Biochemistry and Physiology 81, 113-122.

Obeng-Ofori, D.; Amiteye, S. (2005), Efficacy of mixing vegetable oils with pirimiphos-methyl against the maize weevil, Sitophilus zeamais Motschulsky in stored maize. Journal of Stored Products Research 41, $57-66$.

Oliveira, A. S.; Xavier-Filho, J.; Sales, M. P. (2003), Cysteine Proteinases and Cystatins. Brazilian Archives of Biology and Technology 46, 91-104.

Omar, S.; Lalonde, M.; Marcotte, M.; Cook, M.; Prouxl, J.; Goel, K.; Durst, T.; Philogene B.J.R.; Armason, J.T. (2000), Insect growth - reducing and antifeedant activity in Eastern North America Hardwood species and biossay-guided isolation of active principles from Prunus serotina. Agricultural and Forest Entomology 12, 253-257.

Parra, J. R. P. (1991), Consumo e utilização de alimentos por insetos. In: Panizzi, A.R.; Parra, J.R.P. (Eds). Ecologia nutricional de insetos e suas implicações no manejo de pragas. São Paulo: Manole.

Pautou M. P, Rey D, David J. P, Meyran J. C. (2000), Toxicity of vegetable tannins on crustacea associated with Alpine mosquito breeding sites. Ecotoxicology and Environmental Safety 47, 323-332. 
Peres, M. T. L. P.; Delle Monache, F.; Cruz, A. B.; Pizzolatti, M. G.; Yunes, R. A. (1997), Chemical composition and antimicrobial activity of Croton urucurana Baillon (Euphorbiaceae). Journal of Ethnopharmacology 56, 223-226.

Peres, M. T. L. P., Pizzolatti, M. G., Yunes, R. A., Monache, F. D. (1998), Clerodane diterpenes of Croton urucurana. Phytochemistry .49, 171 - 174.

Rey D, Pautou M. P., Meyran J. C. (1999), Histopathological effects of tannic acid on the midgut epithelium of some aquatic diptera larvae. Journal of Invertebrate Pathology 73, 173-181.

Sauerwein, M.; Sporer, F.; Wink, M. (1993), Insecttoxicity of phorbol esters from Jatropha curcas seed oil. Planta Medica 59, 686.

Shirley, B. W. (2001), Flavonoid biosynthesis. A colorful model for genetics, biochemistry, cell biology, and biotechnology. Plant Physiology 126, 485-493.

Silva I. G, Guimarães V. P., Lima C. G, Silva H. H. G., Elias C. N, Mady C. M., Silva V. V. M., Nery A. P., Rocha K. R, Rocha C, Isac E. (2003), Efeito larvicida e toxicológico do extrato bruto etanólico da casca do caule de Magonia pubescens sobre Aedes aegypti (Diptera, Culicidae) em criadouros artificiais. Revista de Patologia Tropical 32, 73-86.

Silva, H. H. G.; Silva, I. G.; Santos, R. M. G.; Rodrigues-Filho, E.; Elias, C. N. (2004), Larvicidal activity of tannins isolated of Magonia pubescens St. Hil. (Sapindaceae) against Aedes aegypti (Diptera, Culicidae). Revista da Sociedade Brasileira de Medicina Tropical 37,: 396-399.

Simões, C. M. O.; Schenkel, E. P.; Gosman, G.; Mello, J. C. P.; Mentz, L. A.; Petrovick, P. R. (2002),
Metabolismo básico e origem dos metabólitos secundários. Farmacognósia: da planta ao medicamento, Porto Alegre: UFSC.

Solsoloy, A. D. (1993), Insecticidal efficacy of the formulated product and aqueous extract from physic nut, Jatropha curcas L. seed kernel oil on cotton insect pests. Philippine Journal of Science 6, 28-34.

Solsoloy, A. D. (1995), Pesticidal efficacy of the formulated physic nut, Jatropha curcas L. oil on pests of selected field crops. Philippine Journal of Science 124, 59-74.

Suárez, A. I.; Compagnone, R. S.; Salazar-Bookaman, M.M.; Tillett, S.; Delle Monache, F.; Bruges, G. (2003), Antinociceptive and anti-inflammatory effects of Croton malambo bark aqueous extract. Journal of Ethnopharmacology 88, 11-14.

Viegas-Júnior, C. (2003), Terpenes with insecticidal activity: an alternative to chemical control of insects. Química Nova 26, 390-400.

Warchalewski, J.; Gralik, J.; Winiecki, Z.; Nawrot, J.; Piasecka-Kwiatkowska. D. (2002), The effect of wheat a-amylase inhibitors incorporated into wheatbased artificial diets on development of Sitophilus granarius L., Tribolium confusum Duv. and Ephestia kuehniella Zell. Journal of Applied Entomology 126, 161-168. 